\title{
VALUE NETWORK AS A KEY CATEGORY WITHIN EVENT SPORT TOURISM BUSINESS MODEL: THE CASE OF MERCEDES-BENZ UCI MOUNTAIN BIKE DOWNHILL LOŠINJ WORLD CUP 2018
}

\author{
Ana Kersulić \\ Marko Perić
}

https://doi.org/10.20867/tosee.05.49

\begin{abstract}
Purpose - Sport events generate the largest sport-motivated tourist flow. For the organizers, the best way to make the organization of an event easier, and create value for all stakeholders involved, is to design a successful event business model (BM). In addition to the theoretical knowledge, organizers should be familiar with the good practice, which proves that networking and cooperation between different stakeholders are the key to success. This paper, therefore, focuses on studying the value network, an important element of event's BM, which is critical for the success of the event.

Methodology - The Case Study analysis refers to the Mercedes-Benz UCI Mountain Bike Downhill Lošinj World Cup 2018. Interviews with the representatives of main stakeholders were conducted to analyse the involvement of various groups of stakeholders in the event implementation, their contribution and sharing benefits from the project.

Findings - The findings of the study suggest both similarities and differences regarding stakeholders' specific motives and interests for participating in the organization of this event. Some strategies and recommendations for organizers to improve the stakeholder management and value networking within the event's BM concept are proposed.

Contribution - In addition to a strong contribution to the sport management, event management and stakeholder management theory, the research findings and proposed strategies are beneficial to sport practitioners and the organizers of similar events who could avoid mistakes in planning, organizing, financing and leveraging their future events.

Keywords Business models, value network, sport tourism event, stakeholders, Mountain Bike Downhill

\section{INTRODUCTION}

Today, business model (BM) is a popular word in business and management practice. Everyone talks about BMs associating the term with a firm's strategy, competitive advantage, e-commerce, innovation or performance. Clear articulation of its BM is a must for any organization which wants to be relevant, to deliver the value at scale and to sustain itself. Even more, constant scientific research on the BM concept is important not only for the venture creation but for theoretical development of the field as well.
\end{abstract}


ToSEE - Tourism in Southern and Eastern Europe, Vol. 5, pp. 363-374, 2019

A. Kersulić, M. Perić: VALUE NETWORK AS A KEY CATEGORY WITHIN EVENT SPORT ...

Despite constant development in the field and huge efforts made in the last 20 years, there is an obvious inconsistency in definition and constitute elements of a BM. When it comes to tourism, especially sporting events as the most obvious manifestation of sport tourism (Deery, Jago and Fredline 2004), BM research is even scarcer. Since business practice on the one hand, and organizational and system theory on the other, do not tolerate ambiguity and vagueness in definitions, this paper is trying to shed some light on BM for event sport tourism. More precisely, this paper opens the following research question: What is the role and importance of value network within the sport event BM and is it critical for the success of the sport event?

Given this focus, this paper reviews the literature on value networks within BM context and event sport tourism before focusing on the applied methodology and a particular case study. Finally, some concluding remarks and further theoretical and managerial implications are made.

\section{LITERATURE REVIEW}

\subsection{Value Network as part of Business Model}

BM explains the way a company structures its own activities (Onetti, Zucchella, Jones and McDougall-Covin 2012.) It is a simplified and aggregated representation of an organization's underlying core logic and strategic choices for creating sustainable competitive advantage. (Morris, Schindehutte and Allen 2005) As an abstract description of how companies create and capture value, BM is particularly important for practitioners. However, the implementation of BM concept into practice is hampered by the fact that main BM dimensions are not uniquely defined. Many BM proposals were offered in past years (e.g. Abdelkafi and Täuscher 2016; Johnson, Christensen and Kagermann 2008; Osterwalder, Pigneur and Tucci 2005; Perić, Vitezić and Đurkin 2017a, 2017b; Roome and Louche 2016; Zott et al., 2011) and, despite the different approaches and scopes, most authors agree that BM is best described through several categories strongly emphasizing the concept of value, that is, how value is created, delivered and captured. For this reason, most approaches to the BM structure involve elements that reflect dynamic and transformational nature of the businesses. In other words, value proposition, value creation (involving key resources and processes), value capture, and value network are proposed as key BM categories (Perić, Vitezić and Đurkin 2017a). BM is, therefore, considered as a conceptual tool reflecting the business's core value offered to customers, its configured value network to provide that value, and its continued sustainability (Osterwalder et al. 2005). Organizations must develop new $\mathrm{BMs}$, in which both value creation and value capture occur in a value network (Hamel 2000), creating a new value system within which different economic actors (i.e. partners, customers and beneficiaries, suppliers, distribution channels, and other forms of coalition) work together toward the co-creation of value (Perić et al. 2017a).

For the organizations, it is very important to focus on its core capabilities and outsource other activities or cooperate with partners. The importance of various partners could be perceived in carrying out different processes and activities. Partners are crucial for the activities in which the organizer did not have adequate competence such as those of 
ToSEE - Tourism in Southern and Eastern Europe, Vol. 5, pp. 363-374, 2019

A. Kersulić, M. Perić: VALUE NETWORK AS A KEY CATEGORY WITHIN EVENT SPORT

securing the capital needed, environmental protection, security or marketing (Duglio and Beltramo 2017; Perrin-Malterre 2018). The role of partners and various relationships that could be established within such a network is recognized as an important part of the organization's BM. However, the theoretical approaches differ, and value networks are often elaborated as a part of the infrastructure management (e.g. Johnson et al. 2008; Osterwalder et al. 2005) or as a separate BM category (e.g. Chesbrough 2007; Kesting and Günzel-Jensen 2015; Roome and Louche 2016).

Regardless of the approach, value networks or ecosystems (Chesbrough 2007) focus, therefore, on stakeholder involvement (Voelpel, Leibold, and Tekie 2005; Kesting 2015). The systemized stakeholder approach originates from R. Edward Freeman (1984) and his work on corporations' strategies. He adopted the definition of (corporate) stakeholders as "those groups without whose support the organization would cease to exist" (Freeman \& Reed, 1983). With planning, systems theory, corporate social responsibility and the willingness to collaborate stakeholders are playing an important role to the organization. Hence, stakeholders are defined as "any group or individual who can affect or is affected by the achievement of the organization's objectives" (Freeman, 1984). Events' stakeholders and their networks are often multi-sectorial (both public and private) and composed of organizations connected to each other based on mutual exchange (Borgatti et al. 2009; Parent et al. 2017).

In the tourism context, due to the immaterial character of the tourist experience, BMs seems to be more complex than, for instance, in manufacturing industry. Consequently, the categories of tourism stakeholders are very generic and include residents, tourists, employees, government, local business, competitors, activist groups, educational institutions etc. From managerial perspective, efficient stakeholder management deal with groups that can affect the project as well as with groups that the project can affect (Perić, Đurkin and Lamot 2014). Nowadays, stakeholder management in tourism is an inevitable strategy for efficient tourism planning and development with a strong focus on clusters and networks as a source of competitive advantage for tourism stakeholders (Presenza and Cipollina 2010). By collaborating in planning and decision making, stakeholders could avoid the costs of solving conflicts and enhance the coordination an implementation of planned activities.

\subsection{Event Sport Tourism and Stakeholders}

Niches of sport tourism are numerous, and sport tourism can take a variety of specific forms. Although the size of sport events can vary, they generate the largest sportmotivated tourist flow and induce many socio-economic impacts (Kenyon and Bodet 2018; Liu et al. 2017; Müller 2017). Therefore, event sport tourism, as a unique representation of performance, experience and organizational dimensions, makes the core of sport tourism (Deery et al. 2004)

Event sport tourists are usually divided into active (competitors) and passive participants (spectators) (Weed and Bull 2009). However, from the stakeholder management perspective, the list of sport events' participants is much broader. The sport event tourism demand is made up not only of competitors but also of officials, entourage, suppliers, event management, staff members, sponsors, media representatives and VIPs 
ToSEE - Tourism in Southern and Eastern Europe, Vol. 5, pp. 363-374, 2019

A. Kersulić, M. Perić: VALUE NETWORK AS A KEY CATEGORY WITHIN EVENT SPORT

(Masterman 2009). Additionally, support of the local community as well as the local tourism board is also essential for event success (Chalip and McGuirty 2004). While the participation in a sport event is common to all of these participant groups, the motives for participation differ. It could be distinguished between contract agreements (e.g. event management, suppliers), promotion (e.g. sponsors, local governments, VIPs) or experiencing the event (e.g. competitors, spectators).

Consequently, complex relationships arise between the stakeholders and it is an imperative for organizers to know the good practices of networking and cooperation between different stakeholders and to include it into their event's BM. In other words, event organizers need to create a distinct value system gathering various actors from the public, private and/or associative sectors. The previous research on BMs in sport tourism indicate that partners and networks are usually treated as a resource (Perić, Vitezić and Mekinc 2016) but some recent research suggests partner networking should be one of the key BM categories (Perić, Vitezić and Mekinc 2019).

\section{CASE STUDY: MERCEDES-BENZ UCI MOUNTAIN BIKE DOWNHILL LOŠINJ WORLD CUP 2018}

Given the theoretical and practical implications of this paper, a case study approach was chosen. A case study approach allows the usage of multiple data sources and less restricted interpretations of data gathered especially when there are no clear distinctions between the phenomenon and its context (Patton 1990; Yin 2009).

This paper focuses on the UCI Mercedes-Benz Mountain Bike Downhill World Cup race hosted by the city of Veli Lošinj (April $21-23,2018$ ). The mountain bike downhill is fairly new and interesting extreme outdoor sport capable to attract many spectators. UCI Mercedes-Benz Mountain Bike World Cup is World's premiere mountain bike series with rights held by International Cycling Federation (UCI). Rounds are hosted by National Cycling Federations and their partners as is the case of Lošinj Downhill World Cup, the first Downhill World Cup held on the island.

\subsection{Research field}

In the last years, Croatian tourism has been changing from seasonal to all year round with a variety of the offer that attract different tourist segments with diverse content. Because of the specific landscape and natural beauties, it is an ideal location for the development of outdoor sports, especially cycle-tourism. With a good climate and stunning natural scenery, combined with 2,600 sunshine hours the island enjoys every year, Lošinj is a right destination for this extreme sport.

As defined by the organizers, the location of the venue is unique: The venue takes place in Veli Lošinj, a medieval town with approximately 1.000 inhabitants held near the bigger town of Mali Lošinj (approximately 8.000 inhabitants), located 3km NW and connected with a regional road. Veli Lošinj is situated in a small bay on the southeast side of Lošinj island at the foot of St. John's hill. The $1.3 \mathrm{~km}$ long track starts at the top of the St. John (Sveti Ivan) hill above Veli Lošinj, and finishes right by the sea in the 
ToSEE - Tourism in Southern and Eastern Europe, Vol. 5, pp. 363-374, 2019

A. Kersulić, M. Perić: VALUE NETWORK AS A KEY CATEGORY WITHIN EVENT SPORT

centre of town (Picture 1). The track is short but rough and rocky, with several big drops and jumps and a unique street section. It is estimated to be around the $2 \mathrm{~min} 30 \mathrm{sec}$ mark for the fastest downhill racers in the world. The height difference is $240 \mathrm{~m}$ with the point of departure altitude of approximately $245 \mathrm{~m}$.

Picture 1: UCI Mercedes-Benz Mountain Bike World Cup 2018 track map

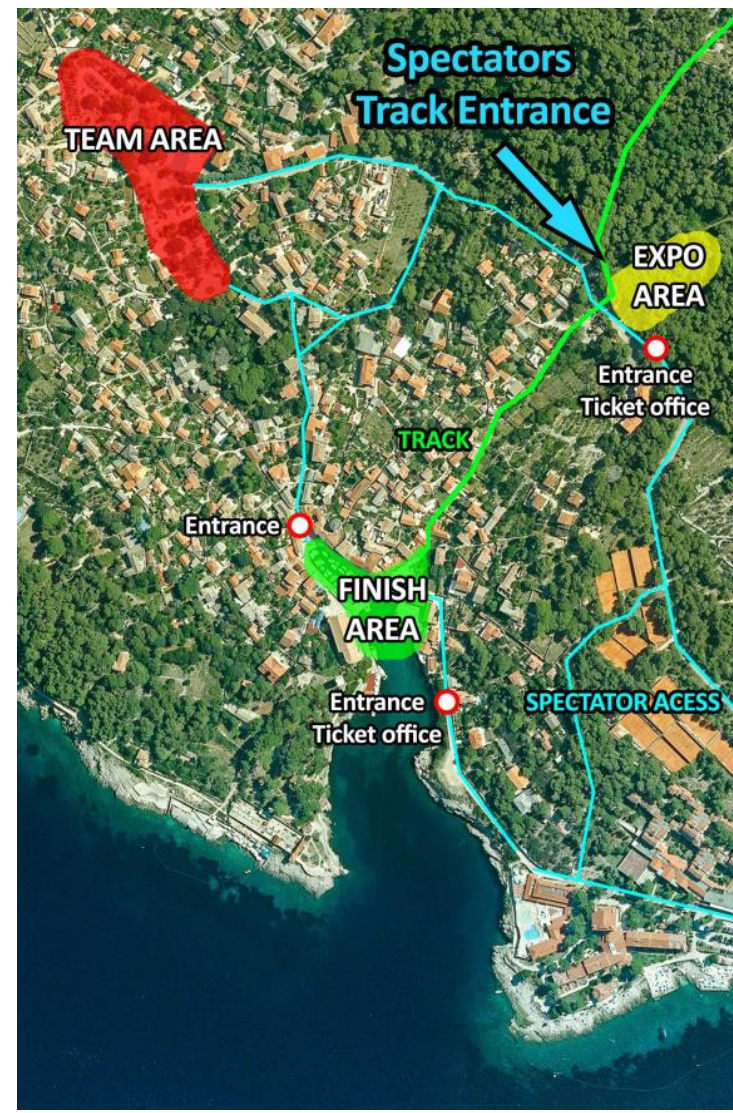

Source: Lošinj World Cup, http://losinjworldcup.com/, 8 January 2019

The event program started earlier in the week for the organizers, sponsors and team members. The visitors were able to participate on the Official Downhill Trainings, Qualifying Rounds and the Finals held from Friday to Sunday. Spectators were able to access the event along the track with entry ticket for a maximum of 3 days. There were around 5.000 visitors in Veli Lošinj, during the event, part of them from the region, but mostly tourists coming from countries where downhill is more common as sport and well recognized (in Croatia is the newest sport). The highest attendance was on the last, Finals day. The overnight stays in hotels in those days increased per 1000 (around 300 were occupied by the organizers). There was no any single bed left in the private accommodation of Veli Lošinj, which were occupied by the visitors and team members. The competitors and their managers and leaders were staying in their tents and campers in the boxes, guarding at the equipment. 
ToSEE - Tourism in Southern and Eastern Europe, Vol. 5, pp. 363-374, 2019

A. Kersulić, M. Perić: VALUE NETWORK AS A KEY CATEGORY WITHIN EVENT SPORT ...

The direct TV broadcast captivated the eyes of an approximate number of millions of people, watching the finals from all around the world. The meaning of this huge number is very significant for the marketing promotion, which affects the image of Croatia and proves the value of the country as an attractive sport tourist location.

The organization and implementation of the event belongs to different stakeholders. Apart from series sponsors, big brands coming from the different parts of the world, the Local Organizing Committees (LOC) are entitled to acquire regional sponsors to cover their expenses and their fees to UCI. It is necessary for the shareholders included in LOC to use all their resources to provide organizational success to the event as well as the goals, in this case the promotion of venue as tourist destination for cyclists and a cycling friendly destination with adequate infrastructure and services (Lošinj World Cup, http://losinjworldcup.com/, 8 January 2019).

\subsection{Data collection and analysis}

Fieldwork was conducted in 2018 and 2019, where the data was collected by direct observation of the destination while attending events and qualitative interviews with key stakeholders. Direct observation took place in April 2018 (i.e. during the event) while the interviews were conducted in January and February 2019 (i.e. after the event). In total, 13 in-depth semi-structured qualitative interviews with key stakeholders involved in planning, organizing and sports tourism service delivery were conducted. Interviews included similar core questions to gain deeper perspectives on stakeholders' motives, experiences and observations on established network cooperation. More precisely, interviews were aimed to analyse the involvement of various groups of stakeholders in the event implementation, their contribution, sharing benefits from the project and suggestions for the future projects focused on the big sports events' organization as promotion of the destination in the field. One author was present during each interview. Each interview lasted on average 30 minutes (from minimum 20 to maximum 45 minutes).

All data was inductively coded following Charmaz's (2006) procedure. Both authors worked independently on analysing and classifying the collected material. When primary categorization was completed, both authors jointly discussed the inconsistencies and finally agreed on the findings.

\subsection{Value Network Analysis}

The analysis of the involvement, contribution and networking between stakeholders and its benefits from the Downhill Lošinj World Cup 2018 project is shown in Table 1. 
ToSEE - Tourism in Southern and Eastern Europe, Vol. 5, pp. 363-374, 2019

A. Kersulić, M. Perić: VALUE NETWORK AS A KEY CATEGORY WITHIN EVENT SPORT ...

Table 1: Analysis of the involvement, contribution and networking between stakeholders and its benefits

\begin{tabular}{|c|c|c|c|c|}
\hline $\begin{array}{l}\text { Stakeholder } \\
\text { category }\end{array}$ & $\begin{array}{c}\text { Level of } \\
\text { involvement }\end{array}$ & $\begin{array}{c}\text { Role and } \\
\text { contribution to } \\
\text { project }\end{array}$ & $\begin{array}{c}\text { Identified } \\
\text { benefits }\end{array}$ & $\begin{array}{c}\text { Suggestions for } \\
\text { future events = } \\
\text { Value network } \\
\text { validation }\end{array}$ \\
\hline LA & $\mathrm{F}: \mathrm{O} \& \mathrm{PR}$ & $\begin{array}{c}\text { Preparation } \\
\text { Supporting the } \\
\text { organisation } \\
\text { Administration } \\
\text { Financial support } \\
\text { Local logistics } \\
\text { Cooperation with the } \\
\text { organizers }\end{array}$ & $\begin{array}{l}\text { Destination \& } \\
\text { region level: } \\
\text { Marketing } \\
\text { Promotion } \\
\text { Summer season } \\
\text { extension } \\
\text { Sports tourism } \\
\text { recognition }\end{array}$ & $\begin{array}{c}\text { Coordination } \\
\text { meetings } \\
\text { Making advantages } \\
\text { from disadvantages } \\
\text { Improve the } \\
\text { organisation and } \\
\text { promotion }\end{array}$ \\
\hline $\mathrm{AOL}$ & F: O\&PR & $\begin{array}{c}\text { Preparation } \\
\text { Coordination } \\
\text { Cooperation with the } \\
\text { production } \\
\text { Cooperation with the } \\
\text { UCI } \\
\text { Event Marketing } \\
\text { Event Promotion }\end{array}$ & $\begin{array}{c}\text { Destination \& } \\
\text { region level: } \\
\text { Promotion } \\
\text { Event level: } \\
\text { Experience for } \\
\text { Mountain Bike } \\
\text { lovers } \\
\text { Added value }\end{array}$ & $\begin{array}{c}\text { Motivation of the } \\
\text { employees and } \\
\text { volunteers } \\
\text { Improve the } \\
\text { organisation and the } \\
\text { results } \\
\text { Coordination } \\
\text { meetings } \\
\end{array}$ \\
\hline PS & P: $\mathrm{O}$ & $\begin{array}{l}\text { Security of the } \\
\text { organizers, } \\
\text { competitors and } \\
\text { visitors }\end{array}$ & $\begin{array}{c}\text { Destination level: } \\
\text { Security } \\
\text { Confidence }\end{array}$ & $\begin{array}{c}\text { Making advantages } \\
\text { from disadvantages } \\
\text { Coordination } \\
\text { meetings }\end{array}$ \\
\hline $\mathrm{A}$ & P: O \& L \& PR & $\begin{array}{c}\text { Hotel } \\
\text { accommodation } \\
\text { Hotel food and } \\
\text { beverage service } \\
\text { Private } \\
\text { accommodation } \\
\text { Promotion of the } \\
\text { event } \\
\text { Self-promotion }\end{array}$ & $\begin{array}{l}\text { Destination level: } \\
\text { Promotion } \\
\text { Sports tourism } \\
\text { recognition } \\
\text { Summer season } \\
\text { extension } \\
\text { Financial value } \\
\text { with increasing } \\
\text { the overnights }\end{array}$ & $\begin{array}{l}\text { Coordination } \\
\text { meetings } \\
\text { Preparations on } \\
\text { time }\end{array}$ \\
\hline LR & $\mathrm{P}: \mathrm{O} \& \mathrm{PR}$ & $\begin{array}{l}\text { Venue acceptance } \\
\text { Promotion of the } \\
\text { venue and } \\
\text { destination }\end{array}$ & $\begin{array}{l}\text { Destination \& } \\
\text { region level: } \\
\text { Promotion } \\
\text { Importance of } \\
\text { event }\end{array}$ & $\begin{array}{c}\text { Preparations on } \\
\text { time }\end{array}$ \\
\hline $\mathrm{M}$ & $\begin{array}{l}\mathrm{P}: \mathrm{O} \\
\mathrm{F}: \mathrm{PR}\end{array}$ & $\begin{array}{l}\text { Offering services } \\
\text { and content } \\
\text { Promotion of the } \\
\text { event, hotels, } \\
\text { destination, region } \\
\text { as sport tourism } \\
\text { location }\end{array}$ & $\begin{array}{l}\text { Region \& world } \\
\text { level: } \\
\text { Mountain biking } \\
\text { development } \\
\text { Promotion }\end{array}$ & $\begin{array}{l}\text { Coordination } \\
\text { meetings } \\
\text { Forming mixed } \\
\text { commissions }\end{array}$ \\
\hline$S$ & P : O \& L \& PR & $\begin{array}{l}\text { Logistics support } \\
\text { Promotion of the } \\
\text { event }\end{array}$ & $\begin{array}{c}\text { Region \& world } \\
\text { level: } \\
\text { Promotion } \\
\text { Self-promotion }\end{array}$ & $\begin{array}{l}\text { Improve the } \\
\text { communication }\end{array}$ \\
\hline
\end{tabular}

Stakeholder category: LA = Local authorities; AOL = Additional local organisers; PS = Public Services; A = accommodation hotels and private rentals; $\mathrm{LR}=$ Local Residents; $\mathrm{M}=$ Media partners; $\mathrm{S}=$ Sponsors.

Level of involvement: $\mathrm{F}=$ full involved; $\mathrm{P}=$ partly involved; $\mathrm{O}=$ organisation; $\mathrm{PR}=$ promotion; $\mathrm{L}=$ logistics Source: Author's research 
ToSEE - Tourism in Southern and Eastern Europe, Vol. 5, pp. 363-374, 2019

A. Kersulić, M. Perić: VALUE NETWORK AS A KEY CATEGORY WITHIN EVENT SPORT

The Local Authorities (LA), Local government and tourist board were fully involved in the project. As the local government's future goal is to create a "bike friendly" destination, they started out by making the Master plan of the development in the sport tourism field, which will include the construction of new bike trail roads and the adaptation of the existing ones. The Mayor of Mali Lošinj recently presented the further development plan for cycle-tourism on the island. The big start towards making Lošinj "bike friendly" destination is to improve sports projects such as the organization of Downhill Lošinj World Cup 2018. With good promotion, all year round tourism on the island is almost guaranteed. The local government and the tourist board agreed on the importance of sport tourism for the worldwide promotion of the destination and approved a focus on this particular market niche.

Mountain Bike Trbovlje and Athletic Club Lošinj representatives, as Additional Local Organizers (AOL), agree with the recognition of the destination as an excellent host for sports events with a long-term goal - a "bike friendly" destination for an all year-round tourism. As earlier mentioned, sport events are generating the largest sport-motivated tourist flow and inducing many socio-economic impacts (Kenyon and Bodet 2018; Liu et al. 2017; Müller 2017). The representatives of local organizers added a suggestion for the next events pointing out the employees and volunteers needs with improving their motivation for a successful event organization.

The Public Services (PS) segment included Police Department, Fire Department, Emergency Service and Security representatives who partly participated and were involved in the event organization. They were involved from the local authorities' and the local organizers' side. From the point of view of Public Sector representatives, the main goal of the event is the security of the audience as the confidence that everything is well covered and safe even during an extreme event, as in this case.

From the Accommodation (A) side, the local hotels company and other private renters (agencies), were partly involved in the organization, logistics and promotion of the event and the location. The representatives agree on the mentioned goals adding their own financial advantages with increasing the overnight stays and the promotion of their services as benefit. The visitor number was approximately 5.000 and the overnight stays in the hotel industry field on the island increased for around 1.000 during the event. The hotel company was also supplying with food and beverage offer the additional selling points ( 3 small houses settled near the track) inside the venue area and the VIPs boat with additional catering.

Local Residents (LR), the island inhabitants, were partly involved in the organisation and promotion of the event and they played a specific and important role: they were the first in row to accept the venue with all the organisational and logistics needs, from no access for motor vehicles into the venue area to closing the main road for motor vehicles from Mali to Veli Lošinj during the event. They firstly understood the meaning of this extreme event and the importance to promote the destination in the sports field. As mentioned before, event sport tourism, as a unique representation of performance, experience and organizational dimensions, makes the core of sport tourism (Deery et al. 2004). 
ToSEE - Tourism in Southern and Eastern Europe, Vol. 5, pp. 363-374, 2019

A. Kersulić, M. Perić: VALUE NETWORK AS A KEY CATEGORY WITHIN EVENT SPORT

The Media partners (M) were fully involved in the implementation of the event creating the content for worldwide promotion of this special extreme sport, the venue, the destination and the region as a sports destination. They agree on the fact that a successful event does not have a purpose, if it is not backed by a quality seasonal or year-round product, in this case: a cycling friendly destination with adequate infrastructure and services.

From the Sponsors (S) point of view, mainly involved as logistics partners, the main benefits are the promotion of the destination as the promotion of their own services during the project. The interviewed representatives mentioned the impossibility of doing their usual daily job and duties during the event as negative aspect of the event. That fact was the only negative aspect of the event organization according to the interviewed population in this research.

All of the interviewed, from the representatives of local authorities, organizers, public services, accommodation renters and residents, to the media partners and sponsors, agreed and have mostly the same thoughts about the future events. For future organisation of events, they suggest more meetings, more coordination between stakeholders and even forming mixed commissions for various parts of event organization and execution. In the mean time they all agreed with the fact, marking it as essential to the event, that it would be impossible to make the execution of the event without the involvement of all the local stakeholders (Tourist Board, the Government, hotel and other private rentals and other hospitalities) and that the synergy here is crucial for establishing an efficient collaboration mechanism. With highlighting joint generation of ideas, mutual trust, and collaboration, among others, they confirmed the value network importance.

The importance of the stakeholders' connection for the success of the Mercedes-Benz UCI Mountain Bike Downhill Lošinj World Cup 2018 is confirmed with the findings of the study. Further, the suggestion is that different stakeholders have specific motives and interests for participating in the organization of this event. The interviewed stakeholders have some common goals: to promote the destination as sport location, profiling and improving the image. They are sensible to the importance of big sport events for tourism development and agreed on the hosting of future events even take part of. Their suggestion for future events organization is the cooperation of stakeholders. The interesting in the findings are the benefits of the interviewed on this event; all of them assert the promotion of the destination instead of making their own benefits that prove the value network and an example of good practice.

Finally, future strategies and recommendations for the organizers to improve the stakeholder management and value networking within the event's business model concept prescribe the presence and active participation of key stakeholders that cover various aspects of organisation (logistics, accommodation, security etc.). This network should be characterised by mutual trust and a certain level of stakeholder's autonomy in implementing the planned activities. As value network, the relationships and collaboration of various stakeholders are as important as the implementation of the event, especially for sustainable and competitive touristic destination, thinking about long-term period. Stakeholder management and business models are the right paths to choose, the 
ToSEE - Tourism in Southern and Eastern Europe, Vol. 5, pp. 363-374, 2019

A. Kersulić, M. Perić: VALUE NETWORK AS A KEY CATEGORY WITHIN EVENT SPORT

strategies for an efficient planning and development of sport tourism. In addition to avoid the costs of solving conflicts and improve the coordination and planned activities implementation for the future events, the collaboration and stakeholders networking are crucial for an efficient execution as for the decision making management.

\section{CONCLUSION}

By analysing the value network as one of the key parts of BM within sport event context, which is still under-researched area of research, this paper makes a strong contribution to the management theory in general and sport management, event management and stakeholder management in particular. The case study method contributed to the better understanding of roles, motives and attitudes of key stakeholders which make this network operational as well as their perceived benefits and costs. The research findings suggest that the key stakeholders of the MTB Lošinj WC2018 belong to the private, public as well as civil sector. From BM perspective, they established unique partnership oriented to the organisation of this particular sport event.

Although the motives to participate in this network differ, most stakeholders agree that each of them has very specific role and that without any of them this network would be insufficient and less cost-effective. Also, they highlighted joint generation of ideas, joint decision making, mutual trust, a certain level of stakeholder's autonomy and visibility within the project as crucial for establishing an efficient collaboration mechanism. The main benefits of the MTB Lošinj WC2018 value network refer to accumulated knowledge of stakeholders, minimising potential risks from the external environment and increased promotion of the destination as a whole. However, financial benefits are also important, especially for stakeholders from tourism (private) sector.

BMs, and value network as a constitute element of the BM, make difference when it comes to conducting the actors in the same direction, that is, achieving the joint objectives. In this process, there is continuous interplay of stakeholders within the network on one side, but also between stakeholders (i.e. value network) and other BM elements. Knowing the two-way value-creating process is beneficial to sport practitioners and the organisers of similar events who could develop strategies for identifying and managing relevant stakeholders and their interests. In such a way they could avoid mistakes in planning, organising, financing and leveraging their future events. It could also increase the number of successfully organised sport events in a destination. It is especially applicable for Croatia which is, because of its advantages on the geographical location, nature and favourable climate conditions even in wintertime, the perfect place for organising outdoor sporting events. These events could provide a new perspective for Croatian tourism and extend the traditional summer tourism season to all year round.

Using the case study method is at the same time a limitation. More cases within the event sport tourism industry will increase the comparability and generalizability of findings. Second, this study surveyed only the primary stakeholders engaged in the event organisation. Competitors and spectators, as well as local residents have been omitted from this study. Inclusion of these stakeholder groups in future research could would 
ToSEE - Tourism in Southern and Eastern Europe, Vol. 5, pp. 363-374, 2019

A. Kersulić, M. Perić: VALUE NETWORK AS A KEY CATEGORY WITHIN EVENT SPORT ...

broaden the scope of the research and provide more profound insights into event BMs and event value network.

\section{REFERENCES}

Abdelkafi, N. and Täuscher K. (2016), "Business Models for Sustainability from a System Dynamics Perspective", Organization \& Environment, Vol. 29, No. 1, pp. 74-96 https://doi.org/10.1177/1086026615592930

Baggio, R. (2006), "Complex systems, information technologies and tourism: a network point of view", Information Technology and Tourism, Vol. 8, No. 1, pp. 15-29.

Borgatti, S.P., Mehra, A., Brass, D.J. and Labianca, G. (2009), "Network Analysis in the Social Sciences", Science, Vol. 323, No. 5916, pp. 892-895.

Chalip, L. and McGuirty, J. (2004), "Bundling sport events with the host destination", Journal of Sport Tourism, Vol. 9, No. 3, pp. 267-282 https://doi.org/10.1080/1477508042000320241

Charmaz, K. (2006), Constructing grounded theory: A practical guide through qualitative analysis, Sage, London.

Chesbrough, H. (2007), "Business model innovation: It's not just about technology anymore", Strategy \& Leadership, Vol. 35, No. 6, pp. 12-17 http://doi.org/10.1108/10878570710833714

Deery, M., Jago, L. and Fredline, L. (2004), "Sport tourism or event tourism: are they one and the same?" Journal of Sport \& Tourism, Vol. 9, No. 3, pp. 235-245.

Downhill World Cup n.d., Lošinj World Cup, viewed 8 of January 2019, http://losinjworldcup.com/

Duglio, S. and Beltramo, R. (2017), "Estimating the Economic Impacts of a Small-Scale Sport Tourism Event: The Case of the Italo-Swiss Mountain Trail CollonTrek", Sustainability, Vol. 9, No. 3, pp. 343.

Freeman, R.E. and Reed, D.L. (1983), "Stockholders and Stakeholders: A new perspective on Corporate Governance", California Management Review, Vol. 25, No. 3, pp. 88-106.

Freeman, R.E. (1984), Strategic Management: A Stakeholder Approach, Pitman, Boston.

Hamel, G. (2000), Leading the Revolution, Harvard Business School Press, Boston.

Johnson, M.W., Christensen, C.M. and Kagermann, H. (2008), "Reinventing Your Business Model", Harvard Business Review, Vol. 86, No. 12, pp. 50-59.

Kenyon, J. A. and Bodet, G. (2018), "Exploring the domestic relationship between mega-events and destination image: The image impact of hosting the 2012 Olympic Games for the city of London", Sport Management Review, Vol. 21, No. 3, pp. 232-249 https://doi.org/10.1016/j.smr.2017.07.001

Kesting, P., Günzel-Jensen, F. (2015), "SMEs and new ventures need business model sophistication", Business Horizons, Vol. 58, pp. 285-293 http://doi.org/10.1016/j.bushor.2015.01.002

Liu, D., Hautbois, C. and Desbordes, M. (2017), "The expected social impact of the Winter Olympic Games and the attitudes of non-host residents toward bidding: The Beijing 2022 bid case study", International Journal of Sports Marketing and Sponsorship, Vol. 18, No. 4, pp. 330-346 https://doi.org/10.1108/IJSMS-11-2017-099

Magretta, J. (2002), “Why Business Models Matter?”, Harvard Business Review, Vol. 80, No. 5, pp. 3-8 https://doi.org/10.12691/jbms-3-2-4

Masterman, G. (2009), Strategic sport event management: Olympic edition, $2^{\text {nd }}$ edition, Elsevier ButterworthHeinemann, Oxford, UK.

Morris, M., Schindehutte, M. and Allen, J. (2005), “The Entrepreneur's Business Model: Toward a Unified Perspective”, Journal of Business Research, Vol. 58, No. 6, pp. 726-735 https://doi.org/10.1016/j.jbusres.2003.11.001

Müller, M. (2017), “Approaching paradox: Loving and hating mega-events”, Tourism Management, Vol. 63, pp. 234- 241 https://doi.org/10.1016/j.tourman.2017.06.003

Onetti, A., Zucchella, A., Jones M.V. and McDougall-Covin, P.P. (2012), "Internationalization, Innovation and Entrepreneurship: Business Models for New Technology-Based Firms", Journal of Management \& Governance, Vol. 16, No. 3, pp. 337-368 http://dx.doi.org/10.1007/s10997-0109154-1

Osterwalder, A., Pigneur, Y., and Tucci, C.L. (2005), "Clarifying Business Models: Origins, Present, and Future of the Concept", Communications of the Association for Information Systems, Vol. 16, pp. 1-25.

Parent, M.M., Rouillard, C. and Naraine, M.L. (2017), "Network governance of a multi-level, multi-sectoral sport event: Differences in coordinating ties and actors", Sport Management Review, Vol. 20, No. 5, pp. 497-509 https://doi.org/10.1016/j.smr.2017.02.001

Patton, M. (1990), Qualitative evaluation and research methods (2nd ed.), Sage, Newbury Park, CA., pp. 532. 
ToSEE - Tourism in Southern and Eastern Europe, Vol. 5, pp. 363-374, 2019

A. Kersulić, M. Perić: VALUE NETWORK AS A KEY CATEGORY WITHIN EVENT SPORT ...

Perić, M., Đurkin, J. and Lamot, I. (2014), "Importance of stakeholder management in tourism project: Case study of the Istra Inspirit project”, 22. Biennial International Congress: Tourism \& Hospitality Industry 2014: Trends in Tourism and Hospitality Industry, University of Rijeka, Faculty of Tourism and Hospitality Management, Opatija, pp. 273-286.

Perić, M., Vitezić V. and Đurkin, J. (2017a), "Business Model Concept: An Integrative Framework Proposal”, Managing Global Transitions, Vol. 15, No. 3, pp. 255-274.

Perić, M., Vitezić, V. and Đurkin, J. (2017b), “The Constructs of a Business Model Redefined: A Half-Century Journey", Sage Open, Vol. 7, No. 3, pp. 1-13 https://doi.org/10.1177/2158244017733516

Perić, M., Vitezić, V. and Mekinc, J. (2016), "Conceptualising innovative business models for sustainable sport tourism”, International Journal of Sustainable Development and Planning, Vol. 11, No. 3, pp. 469482 https://doi.org/10.2495/SDP-V11-N3-469-482

Perić, M, Vitezić, V. and Mekinc, J. (2019 in press), "Comparing business models for event sport tourism: case studies in Italy and Slovenia", Event Management.

Perrin-Malterre, C. (2018), "Tourism diversification process around trail running in the Pays of Allevard (Isère)", Journal of Sport \& Tourism, Vol. 22, No. 1, pp. 67-82 https://doi.org/10.1080/14775085.2018.1432410

Presenza, A. and Cipollina, M. (2010), “Analysing tourism stakeholders networks”, Tourism Review, Vol. 65, No. 4, pp. 17-30., https://doi.org/10.1108/16605371011093845

Roome, N. and Louche, C. (2016), "Journeying toward business models for sustainability: a conceptual model found inside the black box of organisational transformation", Organization \& Environment, Vol 29, No. 1, pp. 11-35 https://doi.org/10.1177/1086026615595084

Voelpel, S.C., Leibold, M., Tekie, E. and von Krogh, G. (2005), "Escaping the Red Queen Effect in Competitive Strategy: Sense-Testing Business, Models", European Management Journal, Vol. 23, No. 1, pp. 37-49 https://doi.org/10.1016/j.emj.2004.12.008

Weed, M. and Bull, C. (2009), Sports Tourism: Participants, Policy and Providers, 2nd ed., Elsevier, Oxford

Wirtz, B.W., Pistoia, A., Ullrich, S. and Göttel, V. (2016), "Business Models: Origin, Development and Future Research Perspectives”, Long Range Planning, Vol 49, No. 1, pp. 36-54 https://doi.org/10.1016/j.lrp.2015.04.001

Yin, R.K. (2009), Case study research: Design and methods (4th ed.), Sage: London, UK.

Zott, C., Amit, R. and Massa L. (2011), “The Business Model: Recent Developments and Future Research", Journal of Management, Vol. 37, No. 4, pp. 1019-1042 https://doi.org/10.1177/0149206311406265

Ana Kersulić, PhD Student

University of Rijeka

Faculty of Tourism and Hospitality Management

Management of Sustainable Development

Primorska 42, 51410 Opatija, Croatia

Phone: +385981849174

E-mail: kersulica@gmail.com

Marko Perić, PhD, Associate Professor

University of Rijeka

Faculty of Tourism and Hospitality Management

Department of Management

Primorska 42, 51410 Opatija, Croatia

Phone: +385 51294191

E-mail: markop@fthm.hr 